\title{
Analisis atribut toko online terhadap repurchase intention dengan mediasi customer satisfaction di Indonesia
}

\author{
Boni Jovianggi \\ Universitas Katolik Indonesia Atma Jaya, Jalan Jenderal Sudirman 51 Jakarta 12930, Indonesia \\ bonijovianggi@yahoo.co.id \\ Yasintha Soelasih* \\ Universitas Katolik Indonesia Atma Jaya, Jalan Jenderal Sudirman 51 Jakarta 12930, Indonesia \\ yasintha.soelasih@atmajaya.ac.id \\ *Penulis Korespondensi
}

Submitted: Sept 02, 2020; Reviewed: Sept 09, 2020; Accepted: Sept 25, 2020

\begin{abstract}
Consumer behavior is currently experiencing changes in shopping. Technological developments cause changes in consumers. Companies see changes in consumer shopping patterns. Consumers buy through not only offline, but also online. Patterns of change are not only for products, but services as well as changes in purchases. This development has led to the emergence of online stores, giving rise to online applications. This study aims to determine whether the attributes of online stores affect repurchase intention in online shopping applications. Besides, this study was also conducted to determine the mediating variable's effect on customer satisfaction on the relationship between online store attributes and repurchase intention. The sampling method used in this study is non-probability sampling with a purposive sampling technique. This study's data were obtained by distributing an online questionnaire to 201 respondents who were account holders and had shopped in an online application. The indicators and variables in this study were tested for their's validity and reliability before being used in data collection. The validity used is confirmatory factor analysis $(C F A)$ and reliability used is composite reliability (CR) and average variance extracted (AVE). This study uses data analysis method of Structural Equation Modeling (SEM) with Lisrel for Windows 8.70 software to test the research hypotheses. This study's results indicate that the attributes of online stores do not directly have a significant effect on repurchase intention. Online store attributes have a significant effect on repurchase intention by mediation of customer satisfaction.
\end{abstract}

Keywords: customer satisfaction; online application; online store attribute; repurchase intention Abstrak: Perilaku konsumen pada saat ini mengalami perubahan dalam berbelanja. Perubahan
konsumen disebabkan terjadinya perkembangan teknologi. Perusahaan melihat perubahan pada pola
berbelanja konsumen. Konsumen tidak hanya membeli melalui offline, tetapi juga melalui online. Pola
perubahan tidak hanya untuk produk, tetapi jasapun juga terjadi perubahan dalam pembelian.
Perkembangan ini yang menyebabkan timbulnya toko online sehingga menimbulkan aplikasi online.
Penelitian ini bertujuan untuk mengetahui apakah atribut toko online berpengaruh terhadap minat
pembelian kembali pada aplikasi belanja online. Selain itu, penelitian ini juga dilakukan untuk
mengetahui pengaruh variabel mediasi kepuasan pelanggan pada hubungan antara atribut toko
online terhadap minat pembelian kembali. Metode pengambilan sampel yang digunakan dalam
penelitian ini adalah non-probability sampling dengan teknik purposive sampling. Data dalam
penelitian ini diperoleh dengan mendistribusikan kuesioner online kepada 201 orang responden yang
merupakan pemilik akun dan pernah berbelanja di aplikasi online. Indikator-indikator dan variabel-
DoI: https://doiorg/10.28932/jmm.v20i1.2910 
variabel pada penelitian ini diuji validitas dan reliabilitasnya sebelum digunakan dalam pengambilan data. Validitas yang digunakan adalah confirmatory factor analysis (CFA) dan reliabilitas yang digunakan adalah composite reliability (CR) dan average varaiance extracted (AVE). Penelitian ini menggunakan metode analisis data Structural Equation Modelling (SEM) dengan software Lisrel for Windows 8.70 untuk menguji hipotesis-hipotesis penelitian. Hasil penelitian menunjukkan bahwa atribut toko online tidak secara langsung berpengaruh signifikan terhadap minat pembelian kembali. Atribut toko online memiliki pengaruh signifikan terhadap minat pembelian kembali dengan mediasi kepuasan pelanggan.

Kata kunci: aplikasi online; atribut toko online; kepuasan pelanggan; minat pembelian kembali

\section{PENDAHULUAN}

Marketplace merupakan situs tempat berkumpulnya penjual dan pembeli secara online, di mana banyak penjual dan pembeli yang menggunakan media ini dengan tujuan transaksi jual-beli secara digital yang lebih aman. Beberapa marketplace yang populer di Indonesia untuk transaksi jual-beli online di antaranya adalah Tokopedia, Bukalapak, Aplikasi online, Lazada, dan Elevenia (Wardani, 2018).

Menurut Brunn, Jensen, \& Skovgaard (2002), e-marketplace adalah tempat dan sarana bagi komunitas bisnis interaktif secara elektronik yang menyediakan pasar. Perusahaan dapat melakukan B2B e-commerce dan atau kegiatan e-business lain. Penggunaan merketplace di Indonesia semakin meningkat setiap tahunnya. Jika diurutkan berdasarkan peringkat kunjungan aplikasi terbanyak, maka Shopee menjadi peringkat pertama kemudian disusul oleh Tokopedia, Bukalapak, dan Lazada (Kharisma, 2019).

Dalam membangun aplikasi online store yang baik, perusahaan memiliki tantangan dan berbagai permasalahan. Tantangan pertama adalah harus menjaga konsistensi dan inovasi dalam atribut toko online pada aplikasi, melalui konten dan tampilan halaman yang menarik, sehingga dapat merefleksikan nilai-nilai dan personality perusahaan kepada pelanggan. Tantangan kedua perusahaan adalah harus membangun kepuasan pelanggan dengan cara menyelesaikan keluhan yang muncul dari pengguna dengan strategi yang cepat dan tepat. Tantangan ketiga adalah menciptakan daya tarik pengguna untuk melakukan kunjungan dan pembelian kembali melalui aplikasi online.

Pada penelitian Dhiranty, Suharjo, \& Suprayitno (2011), atribut toko online seperti user interface quality, information quality, perceived security, dan perceived privacy dapat memengaruhi customer satisfaction. Obyek penelitiannya adalah hanya pengguna aplikasi Tokopedia di wilayah Jakarta dan Bogor. Begitu pula dengan penelitian yang dilakukan oleh Eid (2011) menyatakan bahwa atribut toko online seperti user interface quality, information quality, perceived security, dan perceived privacy dapat memengaruhi customer satisfaction. Penelitian Eid (2011) meneliti pada obyek toko online lokal yang ada di Arab Saudi. Pada penelitian Rachmanda (2016) dijelaskan bahwa tingkat pengaruh atribut toko online pada kepuasan pelanggan online adalah signifikan. Penelitiannya menggunakan obyek pada toko online yang spesifik yaitu butik pakaian. Penelitian yang dilakukan oleh Susilawaty \& Nicola (2020) menunjukkan bahwa layanan perbankan digital memengaruhi kepuasan nasabah. Hal ini menunjukkan bahwa perilaku konsumen mulai berubah dari yang offline menjadi online, baik pada sektor retail maupun jasa perbankan.

Selain kepuasan pelanggan, terdapat faktor lain yang dapat dipengaruhi oleh atribut toko online, yaitu repurchase intention. Menurut Dholakia \& Zhao (2010), atribut toko online dapat berpengaruh signifikan pada customer satifaction dan repurchase intention. Namun, dalam penelitian tersebut dijelaskan bahwa pengaruh tersebut tidak terjadi pada seluruh faktor dalam atribut toko online, hanya faktor-faktor dalam atribut toko online tertentu saja yang dapat memberikan pengaruh yang signifikan. Sedangkan dalam penelitian Lin \& Lekhawipat (2013), Junaidi \& Sugiharto (2015), Suhaily \& Soelasih (2017), Suhaily \& Soelasih (2018), dan Devi \& Sulistyawati (2018) menunjukkan bahwa terdapat pengaruh positif dan signifikan antara customer satisfaction terhadap variabel repurchase intention. Kim, Galliers, Shin, Ryo, \& Kim (2012) menunjukkan bahwa repurchase intention merupakan ketertarikan konsumen untuk melakukan pembelian ulang melalui toko online, yang mana 
konsumen akan mengunjungi toko online kembali di masa depan dan konsumen tertarik untuk merekomendasikan toko online kepada orang di sekitar.

Berdasarkan fenomena di atas, penelitian ini menguji pengaruh atribut toko online terhadap repurchase intention dengan mediasi customer satisfaction. Kontribusi penelitian ini menunjukkan repurchase intention yang terjadi pada aplikasi online. Repurchase intention timbul bila konsumen merasa aman dan mudah dalam melakukan transaksi online.

\section{METODE}

Penelitian ini dilaksanakan dengan cara mendistribusikan kuesioner online kepada masyarakat di Jabodetabek. Responden yang dipilih adalah mereka yang sudah pernah melakukan pembelanjaan produk melalui marketplace. Pendistribusian kuesioner dilakukan selama satu bulan pada tanggal 08 Juni sampai dengan 08 Juli 2020. Metode pengumpulan data dilakukan dengan menggunakan online questionnaire, di mana peneliti menggunakan teknik purposive sampling, yaitu teknik menentukan sampel penelitian dengan beberapa pertimbangan tertentu yang bertujuan agar data yang diperoleh nantinya bisa lebih representative.

Penelitian ini menggunakan tiga variabel yaitu atribut toko online, customer satisfaction, dan repurchase intention. Definisi operasional variabel, dimensi, serta indikatornya dijelaskan pada Tabel 1 berikut.

Tabel 1. Definisi operasional variabel, dimensi, dan indikator penelitian

\begin{tabular}{|c|c|c|c|c|}
\hline Variabel & Definisi & Dimensi & Indikator & Sumber \\
\hline $\begin{array}{l}\text { Atribut toko } \\
\text { online (ATO) }\end{array}$ & $\begin{array}{l}\text { Karakteristik atau } \\
\text { ciri-ciri khusus } \\
\text { yang menjadi ciri } \\
\text { khas dan melekat } \\
\text { pada sebuah toko } \\
\text { online }\end{array}$ & $\begin{array}{l}\text { Tampilan, } \\
\text { informasi, } \\
\text { transaksi } \\
\text { pembayaran, } \\
\text { dan data } \\
\text { pribadi }\end{array}$ & $\begin{array}{l}\text { Tampilan aplikasi, } \\
\text { kemudahan memahami } \\
\text { informasi, kemanan } \\
\text { transaksi pembayaran, dan } \\
\text { kemanan data pribadi }\end{array}$ & Eid (2011) \\
\hline $\begin{array}{l}\text { Customer } \\
\text { satisfaction } \\
\text { (CS) }\end{array}$ & $\begin{array}{l}\text { Evaluasi pelanggan } \\
\text { dari produk atau } \\
\text { layanan dalam hal } \\
\text { apakah produk atau } \\
\text { layanan itu telah } \\
\text { memenuhi } \\
\text { kebutuhan dan } \\
\text { ekspektasi } \\
\text { pelanggan }\end{array}$ & $\begin{array}{l}\text { Perasaan, } \\
\text { kepuasan, } \\
\text { keluhan, dan } \\
\text { ekspektasi }\end{array}$ & $\begin{array}{l}\text { Perasaan senang ketika } \\
\text { berbelanja, kepuasan ketika } \\
\text { berbelanja, keluhan } \\
\text { berbelanja pengguna, dan } \\
\text { kesesuaian ekspektasi } \\
\text { terhadap aplikasi }\end{array}$ & $\begin{array}{l}\text { Lin \& } \\
\text { Lekhawipat, } \\
\text { (2013) }\end{array}$ \\
\hline $\begin{array}{l}\text { Repurchase } \\
\text { intention (RI) }\end{array}$ & $\begin{array}{l}\text { Niat pembelian } \\
\text { ulang, yang } \\
\text { mencerminkan } \\
\text { harapan untuk } \\
\text { membeli ulang } \\
\text { produk atau merek } \\
\text { yang sama }\end{array}$ & $\begin{array}{l}\text { Pembelian, } \\
\text { kunjungan, } \\
\text { dan } \\
\text { rekomendasi }\end{array}$ & $\begin{array}{l}\text { Melakukan pembelian } \\
\text { kembali, mengunjungi } \\
\text { aplikasi lagi di masa depan, } \\
\text { dan merekomendasikan } \\
\text { aplikasi kepada orang di } \\
\text { sekitar }\end{array}$ & $\begin{array}{l}\text { Kim et al. } \\
(2012)\end{array}$ \\
\hline
\end{tabular}

Sumber: Diolah dari beberapa artikel

Jumlah responden yang terambil sebanyak 201 orang. Kuesioner terdiri dari pertanyaan yang berkaitan dengan profil responden dan pertanyaan yang tersusun dari indikator-indikator pembentuk variabel. Pertanyaan kuesioner dibuat menggunakan skala Likert dengan bobot 1 sampai dengan 5 . Peneliti melakukan uji reliabilitas dan validitas pada indikator dan variabel yang digunakan dalam penelitian. Uji validitas menggunakan confirmatory factor analysis (CFA) dan reliabilitas menggunakan composite reliability (CR) dan analysis variance extracted (AVE).

Analisis data pada penelitian ini menggunakan model persamaan struktural (SEM) untuk menguji hipotesis karena memiliki kemampuan untuk memerkirakan berbagai hubungan dan saling keterkaitan 
hubungan ketika menerangkan kesalahan pengukuran dalam proses estimasi (Hair, Black, Babin, Anderson, \& Tatham, 2015). Analisis SEM yang digunakan dengan Lisrel versi 8.7.

\section{HASIL DAN PEMBAHASAN}

\subsection{Data responden}

Penelitian ini dilakukan dengan menyebarkan kuesioner online kepada masyarakat Jabodetabek yang memiliki akun marketplace dan pernah melakukan pembelian produk melalui aplikasi. Responden yang diperoleh sejumlah 201 orang responden. Karakteristik-karakteristik responden pada penelitian ini dijelaskan pada Tabel 2.

Tabel 2. Karakteristik responden

\begin{tabular}{|c|c|c|c|}
\hline No. & Karakterisitik & Jumlah responden & Persentase \\
\hline \multirow[t]{3}{*}{1} & Jenis kelamin & & \\
\hline & Pria & 51 & $25,4 \%$ \\
\hline & Wanita & 150 & $74,6 \%$ \\
\hline \multirow[t]{5}{*}{2} & Usia & & \\
\hline & 15-25 Tahun & 19 & $9,5 \%$ \\
\hline & 26-35 Tahun & 156 & $77,6 \%$ \\
\hline & 36-45 Tahun & 23 & $11,4 \%$ \\
\hline & 46-55 Tahun & 3 & $1,5 \%$ \\
\hline \multirow[t]{6}{*}{3} & Jenis pekerjaan & & \\
\hline & Ibu rumah tangga & 11 & $5,5 \%$ \\
\hline & Pelajar/ Mahasiswa & 10 & $5 \%$ \\
\hline & Wiraswasta & 32 & $15,9 \%$ \\
\hline & Pegawai swasta & 141 & $70,1 \%$ \\
\hline & Pegawai negeri sipil & 7 & $3,5 \%$ \\
\hline \multirow[t]{4}{*}{4} & Pengeluaran per bulan & & \\
\hline & Rp 100.000-Rp 500.000 & 135 & $67,2 \%$ \\
\hline & Rp 500.001-Rp. 1.000 .000 & 57 & $28,4 \%$ \\
\hline & $>\operatorname{Rp} 1.000 .000$ & 9 & $4,5 \%$ \\
\hline
\end{tabular}

Sumber: Hasil pengolahan aplikasi SPSS (2020)

Tabel 2 menunjukkan bahwa responden wanita sebanyak 74,6\%, artinya bahwa wanita cenderung memiliki minat untuk berbelanja tinggi walaupun dengan menggunakan aplikasi. Usia yang suka berbelanja melalui online pada rentang antara 26-35 tahun sebanyak 77,6\%, di mana pada usia tersebut mereka sudah bekerja, sehingga memunyai penghasilan untuk dibelanjakan melalui online. Pekerjaan terbanyak pada pegawai swasta sebesar $70,1 \%$ dan pengeluaran mereka per bulan untuk belanja online antara Rp. 100.000-Rp. 500.000 sebesar 67,2\%. Data ini menunjukkan bahwa pegawai swasta dengan jumlah dana yang dibelanjakan dengan menggunakan aplikasi online menjadi responden terbanyak pada rentang pegeluaran per bulan Rp. 100.000-Rp. 500.000.

\subsection{Hasil uji validitas dan reliabilitas}

Data dalam penelitian ini dinyatakan valid apabila loading standard $>0,3$ dan composite reliability di atas 0,6 menurut Bagozzi \& Yi (1988). Jika indikator pengukuran tidak layak, maka perlu dilakukan modifikasi model hingga memenuhi uji validitas. Nilai analysis variance extracted $\geq 0,50$, menunjukkan adanya convergent (Ghozali \& Fuad, 2018). Hasil pengujian validitas dan realibilitas penelitian ini tersaji pada Tabel 3 berikut. 
Tabel 3. Hasil validitas dan reliabilitas

\begin{tabular}{lllllll}
\hline Variabel & Indikator & $\begin{array}{l}\text { Standard } \\
\text { loading }\end{array}$ & $\begin{array}{c}\text { (Standard } \\
\text { loading) } \\
\left(\chi^{2}\right)\end{array}$ & $\begin{array}{c}\text { Error } \\
(\varepsilon j)\end{array}$ & $C R$ & AVE \\
\hline Atribut toko & ATO1 & 0,49 & 0,24 & 0,76 & 0,72 & 0,5 \\
online & ATO2 & 0,61 & 0,37 & 0,63 & & \\
& ATO3 & 0,38 & 0,14 & 0,86 & 0,80 & 0,54 \\
Customer & CS1 & 0,8 & 0,64 & 0,36 & 0,80 & \\
satisfaction & CS2 & 0,89 & 0,79 & 0,21 & & \\
& CS3 & 0,58 & 0,34 & 0,66 & & \\
Repurchase & CS4 & 0,51 & 0,26 & 0,74 & & \\
intention & RI & 0,88 & 0,77 & 0,23 & 0,71 & 0,52 \\
& RI2 & 0,61 & 0,37 & 0,63 & & \\
\hline
\end{tabular}

Sumber: Hasil pengolahan aplikasi Lisrel versi 8.7 (2020)

\subsection{Hasil uji normalitas dan multikolinearitas}

Data yang digunakan dalam penelitian ini diuji menggunakan uji normalitas dan multikolinearitas. Menurut Ghozali \& Fuad (2018), data yang memiliki normalitas yang baik adalah data yang nilai Z skewnessnya tidak lebih dari 2 dan nilai $\mathrm{Z}$ kurtosisnya tidak lebih dari 7. Pengujian normalitas dilakukan dengan menggunakan normal scores pada aplikasi Lisrel versi 8.7. Hasil perhitungan nilai skewness dan kurtosis pada Tabel 4 menunjukkan bahwa terdapat nilai skewness kurang dari dua dan tidak ada nilai kurtosis yang lebih dari tujuh. Berdasarkan perhitungan tersebut, dapat dikatakan bahwa data seluruh variabel memiliki tingkat normalitas yang baik, sehingga asumsi normalitas data SEM terpenuhi.

Tabel 4. Skewness dan kurtosis uji normalitas

\begin{tabular}{llll}
\hline Kode & \multicolumn{1}{c}{ Indikator } & Skewness & Kurtosis \\
\hline ATO1 & $\begin{array}{l}\text { Aplikasi } \text { online memiliki tampilan } \\
\text { halaman yang menarik }\end{array}$ & $-1,805$ & $-0,473$ \\
ATO2 & $\begin{array}{l}\text { Aplikasi } \text { online menyediakan informasi } \\
\text { yang mudah dipahami }\end{array}$ & $-1,941$ & $-1,141$ \\
ATO3 & $\begin{array}{l}\text { Aplikasi } \text { online memberikan kemanan } \\
\text { dalam transaksi pembayaran }\end{array}$ & 1,650 & 4,214 \\
ATO4 & $\begin{array}{l}\text { Data pribadi tersimpan aman di } \\
\text { aplikasi } \text { online }\end{array}$ & $-0,806$ & 2,185 \\
CS1 & $\begin{array}{l}\text { Perasaan senang ketika berbelanja di } \\
\text { aplikasi } \text { online }\end{array}$ & 0,204 & 1,853 \\
CS2 & $\begin{array}{l}\text { Kepuasan ketika berbelanja di aplikasi } \\
\text { online }\end{array}$ & $-0,704$ & 0,566 \\
CS3 & $\begin{array}{l}\text { Tidak ada keluhan berbelanja di } \\
\text { aplikasi } \text { online }\end{array}$ & $-2,282$ & 5,103 \\
CS4 & $\begin{array}{l}\text { Layanan yang sesuai ekspektasi ketika } \\
\text { berbelanja di aplikasi online }\end{array}$ & $-1,519$ & $-0,354$ \\
RI1 & $\begin{array}{l}\text { Melakukan pembelian lagi melalui } \\
\text { aplikasi } \text { online }\end{array}$ & $-1,882$ & $-1,276$ \\
RI2 & $\begin{array}{l}\text { Mengunjungi aplikasi online lagi di } \\
\text { masa depan }\end{array}$ & $-5,782$ & 0,713 \\
RI3 & $\begin{array}{l}\text { Merekomendasikan aplikasi } \text { online } \\
\text { sebagai situs belanja kepada orang- } \\
\text { orang di sekitar }\end{array}$ & $-0,831$ & 0,380 \\
\hline
\end{tabular}

Sumber: Hasil pengolahan aplikasi Lisrel versi 8.7 (2020)

Asumsi multikolinearitas akan memberikan justifikasi bahwa tidak terdapat kolerasi sempurna atau besar di antara variabel independen (Ghozali \& Fuad, 2018). Nilai korelasi antara variabel independen yang tidak diperbolehkan adalah sebesar 0,9 atau lebih. Korelasi di antara variabel independen $<0,9$, dengan demikian tidak terdapat persoalan multikolinearitas, di mana korelasi di antara variabel bebas 
Jurnal Manajemen Maranatha a Vol. 20 Nomor 1, November (2020)

(correlation independent variabel $<0,9$ ). Berdasarkan perhitungan di Tabel 5, maka data empiris yang digunakan memenuhi asumsi multikolinearitas.

Tabel 5. Hasil uji multikolinearitas

\begin{tabular}{lrrrrrr}
\hline & ATO1 & ATO2 & ATO3 & ATO4 & CS1 & CS2 \\
\hline ATO1 & & & & & & \\
ATO2 & 0,247 & & & & & \\
ATO3 & $-0,019$ & 0,027 & & & & \\
ATO4 & 0,161 & 0,227 & 0,460 & & & \\
CS1 & 0,272 & 0,253 & 0,336 & 0,389 & & \\
CS2 & 0,405 & 0,235 & 0,222 & 0,442 & 0,722 & \\
CS3 & 0,461 & 0,340 & 0,120 & 0,414 & 0,375 & 0,489 \\
CS4 & 0,403 & 0,350 & 0,196 & 0,377 & 0,366 & 0,383 \\
\hline
\end{tabular}

Sumber: Hasil pengolahan aplikasi Lisrel versi 8.7 (2020)

\subsection{Uji goodness of fit}

Bagan di bawah ini menggambarkan model penelitian yang merupakan hasil dari pengunaan software Lisrel versi 8.70 .

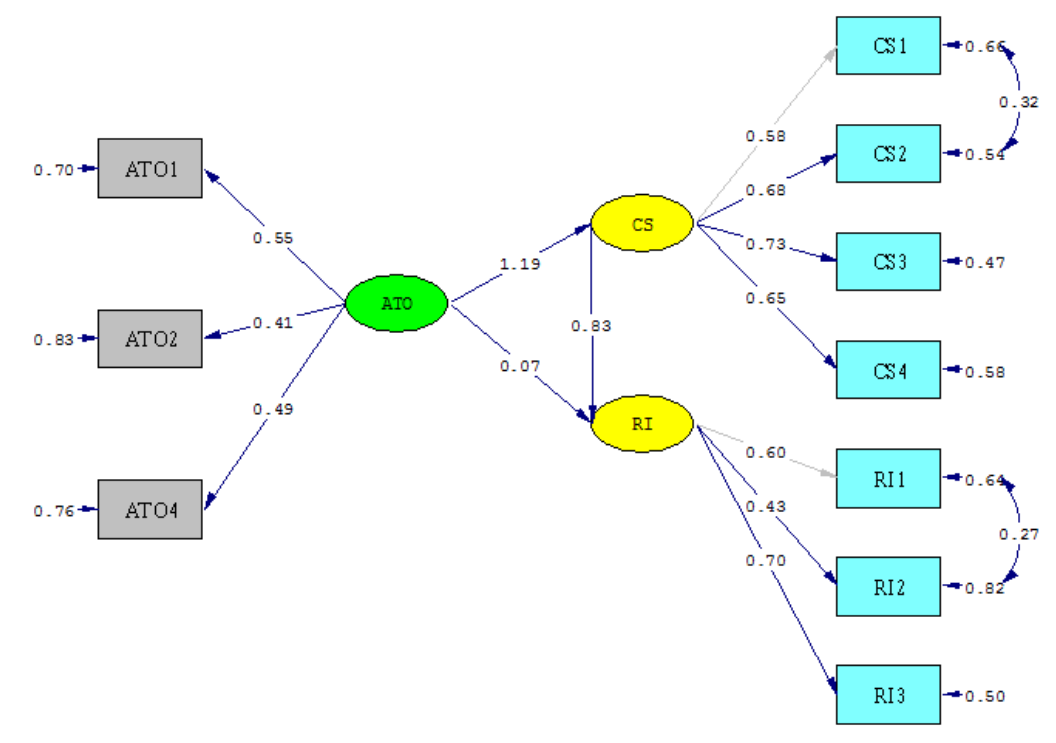

Chi-Square $=53.20, \mathrm{df}=2, \mathrm{P}$-value $=0.00563, \mathrm{RMSEA}=0.062$

Gambar 1. Bagan model struktural berdasarkan standardized solution Sumber: Hasil pengolahan aplikasi Lisrel versi 8.7 (2020)

Gambar 1 menunjukkan analisis terhadap beberapa indeks kesesuaian untuk menguji apakah sebuah model dapat diterima atau ditolak (Ferdinand, 2012).

Tabel 6 Ukuran goodness of fit

\begin{tabular}{lccl}
\hline Goodness of fit index & $\begin{array}{l}\text { Nilai yang } \\
\text { direkomendasikan }\end{array}$ & Hasil & Keterangan \\
\hline$X^{2}$ (Chi-Square) & $\begin{array}{c}\text { Diharapkan kecil } \\
\text { Significant probability }(p\end{array}$ & 53,20 & Good Fit \\
Value) & $\geq 0,05$ & 0,0021 & Unfit \\
RMSEA & $\geq 0,08$ & 0,062 & Good Fit \\
GFI & $\geq 0,90$ & 0,95 & Good Fit \\
AGFI & $\leq 0,90$ & 0,91 & Good Fit \\
CMIN/DF & $\geq 0,00$ & 2 & Good Fit \\
TLI/IFI & $\geq 0,95$ & 0,96 & Good Fit
\end{tabular}


Uji kelayakan model seperti telah dijelaskan pada Tabel 6, yang dalam praktiknya sangat sulit bisa memenuhi kriteria uji kelayakan model secara menyeluruh. Hair et al. (2015) menyatakan bahwa suatu model penelitian dikatakan layak apabila paling tidak salah satu standar uji kelayakan terpenuhi dan akan jauh lebih baik bila standar uji kelayakan model memenuhi lebih dari satu kriteria uji kelayakan atau bahkan seluruhnya. Dengan demikian, berdasarkan penjelasan di atas, dapat disimpulkan bahwa model penelitian ini layak atau fit.

\subsection{Analisis struktural}

Hasil analisis struktural dapat dilihat dari koefisien determinasi $\left(\mathrm{R}^{2}\right)$, koefisien regresi, dan loading factor ( $t$-value) antar latent variable. Koefisien determinasi $\left(\mathrm{R}^{2}\right)$ mengukur mampu atau tidaknya exogen variables menjelaskan secara positif endogen variable. Nilai koefisien regresi penting untuk menentukan arah hubungan antar latent variable. T-value digunakan sebagai prediktor signifikansi hubungan antar pengaruh variabel. Tiga informasi tersebut terlihat pada hasil olah data dengan Lisrel versi 8.7 yang ditampilkan dalam bentuk persamaan struktural sebagai berikut.

Persamaan struktural 1:

$$
\begin{array}{cc}
\text { CS }=1,19 * \text { ATO, Errorvar } & =-0,42, \mathrm{R}^{2}=0,62 \\
(0,15) & (0,20) \\
7,86 & -2,07
\end{array}
$$

Persamaan struktural 2:

$$
\begin{array}{ccc}
\mathrm{RI}=0,83^{*} \mathrm{CS}+0,068^{*} \mathrm{ATO}, \text { Errorvar }= & 0,18, \mathrm{R}^{2}=0,82 \\
(0,24) & (0,20) & (0,13) \\
3,38 & 0,33 & 1,38
\end{array}
$$

Hasil dari persamaan struktural-1 menunjukkan bahwa customer satisfaction (CS) secara simultan dipengaruhi oleh atribut toko online (ATO), dengan nilai koefisien determinasi sebesar 0,62. Artinya, tinggi rendahnya customer satisfaction secara simultan dipengaruhi oleh baik atau buruknya atribut toko online. Standard error variabel atribut toko online yaitu sebesar 0,15; koefisien regresi atribut toko online yaitu sebesar 1,19, sehingga dapat dikatakan bahwa atribut toko online memiliki hubungan yang searah. Artinya, semakin baik atribut toko online yang tersedia, maka semakin tinggi tingkat customer satisfaction. Signifikansi pengaruh variabel atribut toko online terhadap customer satisfaction diukur dengan melihat $t$-value yaitu sebesar 7,86.

Hasil dari persamaan struktural-2 menunjukkan bahwa repurchase intention secara simultan dipengaruhi oleh customer satisfaction (CS) dengan nilai koefisien determinasi sebesar 0,82. Artinya, besarnya repurchase intention dipengaruhi oleh tingkat tinggi rendahnya kepuasan pelanggan dan atribut toko online, yakni sebesar $82 \%$, sedangkan selebihnya $18 \%$ dipengaruhi variabel lain dengan parameter error variance sebesar 0,18. Standard erorr atribut customer satisfaction yaitu sebesar 0,24 dan atribut toko online sebesar 0,20 di mana koefisien regresi customer satisfaction sebesar 0,83 dengan nilai $t$-value 3,38 dan koefisien regresi atribut toko online yaitu sebesar 0,068 dengan nilai $t$ value 0,33, sehingga dapat dikatakan bahwa customer satisfaction (CS) memiliki pengaruh signifikan terhadap repurchase intention (RI), sedangkan atribut toko online (ATO) tidak berpengaruh signifikan terhadap repurchase intention (RI).

\subsection{Pembahasan}

Penelitian ini membuktikan bahwa atribut toko online tidak mempengaruhi repurchase intention secara langsung, tetapi atribut toko online mempengaruhi repurchase intention melalui customer satisfaction. Hasil penelitian ini memiliki perbedaan dengan hasil penelitian terdahulu yang dijadikan acuan dalam penelitian ini. Hasil penelitian ini tidak mendukung penelitian Dholakia \& Zhao (2010), 
di mana atribut toko online tidak berpengaruh secara tidak langsung terhadap repurchase intention. Namun, kedua penelitian ini memiliki kesamaan, yaitu atribut toko online memengaruhi customer satisfaction. Selain itu, penelitian ini sejalan dengan hasil penelitian Curtis, Abratt, Dion, \& Rhoades (2011), Junaidi \& Sugiharto (2015), Suhaily \& Soelasih (2017), Lagita \& Briliana (2018), Suhaily \& Soelasih (2018), dan Devi \& Sulistyawati (2018) di mana penelitian tersebut menguji pengaruh customer satisfaction terhadap repurchase intention dengan hasil menunjukkan bahwa customer satisfaction memengaruhi repurchase intention.

Hasil penelitian ini juga mendukung penelitian Eid (2011) dan Dhiranty et al. (2011), yaitu atribut toko online memengaruhi customer satisfaction. Berdasarkan hasil pengujian dalam penelitian ini, atribut yang terdapat pada toko online tidak memberikan pengaruh signifikan dalam upaya untuk meningkatkan repurchase intention. Aplikasi online sebagai obyek yang diteliti dalam penelitian ini memiliki atribut toko online seperti tampilan halaman yang menarik, informasi yang mudah dipahami, keamanan dalam bertransaksi, dan menjaga kerahasiaan data penggunanya. Namun, kemungkinan hal tersebut tidak cukup dalam konteks atribut toko online untuk memengaruhi repurchase intention oleh konsumennya secara langsung. Strategi manajemen pemasaran yang andal diperlukan dalam kelangsungan usaha khususnya toko online. Faktor lain yang kemungkinan dapat memengaruhi repurchase intention oleh konsumen adalah seperti review atau testimoni konsumen terhadap toko online sebagaimana hal ini terdapat pada aplikasi online. Selain itu, faktor lainnya adalah dengan membangun reputasi toko online yang baik, misalnya star seller, gold store, dan sebagaimana terdapat pada aplikasi online yang secara umum sangat memungkinkan untuk memengaruhi repurchase intention.

Setelah dilakukan pengujian pada hipotesis-hipotesis penelitian, selanjutnya peneliti merumuskan langkah-langkah yang dapat dilakukan demi pengembangan kebijakan manajerial yang diharapkan mampu memberikan sumbangan secara teoretis pada praktik manajemen, khususnya manajemen pemasaran, dalam hal ini terkait atribut toko online dan customer satisfaction memengaruhi repurchase intention calon konsumen pada aplikasi belanja. Suatu perusahaan yang menjalankan bisnis dan menjual produknya melalui aplikasi online harus lebih mengantisipasi dengan berbagai faktor yang melatarbelakangi calon konsumen untuk bersedia atau tidak bersedia melakukan pembelian di toko online. Jika perusahaan dapat meningkatkan faktor-faktor yang membuat calon konsumen untuk melakukan pembelian, maka akan menimbulkan pembelian pertama kali oleh konsumen. Daya tarik yang dibuat oleh perusahaan online akan dapat menimbulkan peningkatan penjualan, sehingga perusahaan dapat terus berkembang dan mempertahankan eksistensinya di dunia bisnis.

\section{SIMPULAN DAN SARAN}

Hasil penelitian ini mengungkapkan bahwa atribut toko online tidak memengaruhi repurchase intention secara langsung. Penelitian ini menyimpulkan bahwa atribut toko online memengaruhi repurchase intention melalui customer satisfaction pada konsumen di Indonesia. Atribut toko menjadi perhatian bagi aplikasi online agar konsumen puas.

Perusahaan sebagai marketplace atau toko online, di mana memerjualkan barang-barang dengan harga ratusan ribu hingga ratusan juta rupiah, harus aware bahwa tidak semua calon konsumen memiliki keinginan untuk melakukan belanja daring dalam nominal besar. Hal ini dapat dikarenakan kekurangpahaman tentang penggunaan aplikasi, keamanan data pribadi, dan masalah kemanan dalam melakukan transaksi pembayaran barang. Strategi manajemen pemasaran yang baik juga tentunya diperlukan dalam kelangsungan bisnis online saat ini. Hal ini dapat memengaruhi konsumen agar melakukan kegiatan pembelian barang secara daring dengan nominal besar. Pengaruh tersebut dapat menentukan rasa kepuasan konsumen setelah menggunakan aplikasi belanja online. Selain itu, dengan atribut toko online, seperti tampilan halaman yang menarik, informasi yang tersedia mudah untuk dipahami, keamanan data pribadi, serta transaksi pembayaran yang aman, dapat membuat konsumen merasa senang dan puas. Begitu pula dengan tersedianya atribut toko yang baik, maka layanan yang dihasilkan sesuai dengan ekspektasi konsumen, sehingga keluhan terhadap penggunaan aplikasi online 
relatif sedikit. Kepuasan konsumen yang baik dapat berpengaruh pada konsumen untuk melakukan repurchase intention. Konsumen mengunjungi aplikasi online di masa yang akan datang bahkan merekomendasikan aplikasi online kepada kerabat terdekat. Hal ini tentunya merupakan nilai positif bagi aplikasi online untuk terus berkembang dan memiliki sustainability yang baik di dunia bisnis marketplace.

Keterbatasan dalam penelitian ini adalah jumlah responden yang kurang banyak, wilayah pengambilan responden yang terbatas, dan teknik pengambilan data yang dilakukan dengan purposive sampling, sehingga penelitian tidak menunjukkan hasil yang representatif. Pada saat ini sudah terjadi perubahan perilaku dalam pembelian, tidak hanya offline tetapi pembelian online semakin tinggi. Oleh karena itu, penelitian tentang online marketing dapat dikembangkan lebih luas lagi. Begitu juga dengan obyek penelitian, dapat dipilih secara spesifik, misalkan pada fashion, makanan, peralatan olah raga, dan lain-lain. Demikianlah, hasil penelitian seyogianya dapat menunjukkan adanya perkembangan teori maupun aplikasi dalam dunia industri, terutama online.

\section{REFERENSI}

Bagozzi, R., \& Yi, Y. (1988). On the evaluation of structural evaluation models. Journal of the Academy of Marketing Science, 16(1), 74-94. Diperoleh dari https://www.researchgate.net/profile/Youiae Yi/publication/225359099.

Brunn, P., Jensen, M., \& Skovgaard. J. (2002). E-marketplace: Crafting a wining strategy. European Management Journal, 20(1), 101-130. Diperoleh dari https://econpapers.repec.org/article/eeeeurman/v_3a20_3ay_3a2002_3ai_3a3_3ap_3a286-298.htm.

Curtis, T., Abratt, R., Dion, P., \& Rhoades, D. L. (2011). Customer satisfaction, loyalty and repurchase. Journal Management Marketing Daytona Beach, 32(1), 47-57. Diperoleh dari https://commons.erau.edu/db-management/20.

Devi, P. S. C., \& Sulistyawati, S. (2018). Peran customer satisfaction memediasi pengaruh online trust terhadap repurchase intention. Jurnal Manajemen Unud, 7(6), 2856-2886. doi:10.24843/EJMUNUD.2018.v07.i06.p01.

Dhiranty, A., Suharjo, B., \& Suprayitno, S. (2017). Analysis on customer satisfaction, trust and loyalty toward online shop (A case study of Tokopedia.com). Indonesian Journal of Business and Entrepreneurship, 3(2), 112-133. doi:10.17358/ijbe.3.2.102.

Dholakia, R. R., \& Zhao, M. (2010). Effect of online store attributes on customer satisfaction and repurchase intentions. International Journal of Retail and Distribution Management, 38(7), 482496. doi:10.1108/09590551011052098.

Eid, M. (2011). Determinants of e-commerce customer satisfaction, trust, and loyalty in Saudi Arabia. Journal of Electronic Commerce Research, 12(1), 13-18. Diperoleh dari https://www.researchgate.net/publication/228867201_Determinants_of_ECommerce_Customer_Sa tisfaction_Trust_and_Loyalty_in_Saudi_Arabia.

Ferdinand, A. (2012). Metode penelitian manajemen. Semarang: Badan Penerbit Universitas Diponegoro.

Ghozali, I., \& Fuad. (2018). Structural equation modeling: Teori, konsep, dan aplikasi dengan program Lisrel 8.80. Semarang: Badan Penerbit Universitas Diponegoro.

Hair, J. F., Jr., Black, W. C., Babin, B. J., Anderson, R. E., \& Tatham, R. L. (2015). Multivariate data analysis. 5th Edition. New Jersey: Prentice-Hall, Inc.

Junaidi, N. W., \& Sugiharto, S. M. (2015). Analisa pengaruh customer value terhadap repurchase intention dengan customer satisfaction sebagai variabel intervening di Pisa Kafe Manyar Surabaya. Jurnal Manajemen Pemasaran Petra, 3(1), 71-87. Diperoleh dari http://publication.petra.ac.id/index.php/manajemen-pemasaran/article/view/3342.

Kharisma, G. (2019, Oktober 17). Peta persaingan 50 e-commerce di Indonesia versi Iprice 2019. Diperoleh dari https://id.techinasia.com/persaingan-ecommerce-indonesia-q3-2019.

Kim, C., Galliers, R. D., Shin, N., Ryoo, J-H., \& Kim, J. (2012). Factors influencing internet shopping value and customer repurchase intention. Electronic Commerce Research and Applications, 11(4), 374-387. doi:10.1016/j.elerap.2012.04.002.

Lagita, L., \& Briliana, V. (2018). Pengaruh customer satisfaction, adjusted expectation, perceived value, dan perceived usefullness terhadap repurchase intention pada pelanggan Lazada. Jurnal Wira Ekonomi Mikroskil, 8(1), 18-25. Diperoleh dari http://garuda.ristekbrin.go.id/documents/detail/888612.

Lin, C., \& Lekhawipat, W. (2013). Factors affecting online repurchase intention. Industrial Management \& Data Systems, 114(4), 597-611. doi:10.1108/IMDS-10-2013-0432. 
Rachmanda, Y. S. (2016). Pengaruh online store atribut terhadap kepercayaan, kepuasan dan loyalitas konsumen online pada perusahaan online Pelangi Boutiqe. Jurnal Manajemen dan Bisnis Siliwangi, 2(1), 61-80. doi:10.1308/jpmanajemendd130881.

Suhaily, L., \& Soelasih, Y. (2017). What effect repurchase intention of online shopping. International Business Research, 10(12), 114-120. doi:10.5539/ibr.v10n12p113.

Suhaily, L., \& Soelasih, Y. (2018). How e-service quality, experiential marketing, and price perception to make repurchase intention on on-line shopping?. The International Journal of Business Management and Technology, 2(3), 10-20. Diperoleh dari http://www.theijbmt.com/archive/0921/2043938013.pdf.

Susilawaty, L., \& Nicola, N. (2020). Pengaruh layanan perbankan digital pada kepuasan nasabah perbankan. Jurnal Manajemen Maranatha, 19(2), 179-190. doi:10.28932/jmm.v19i2.2478.

Wardani, A. (2018, Juli 12). Perkembangan bisnis marketplace. Diperoleh dari https://www.liputan6.com/tekno/read/3585699/ini-5-e-commerce-paling-top-di-indonesia-versiiprice-siapa-saja. 